Australian space

\section{Plan to win more business}

\section{Canberra}

THE Australian Commonwealth Scientific and Industrial Research Organization (CSIRO) has set up a body to coordinate its own space and communications research. The aim is to encourage Australian industrial companies to the point where they will gain sufficient experience to compete internationally for parts of the growing satellitebased communications market. The new unit will be known as the CSIRO Office for Space Science and Applications (COSSA).

It is perhaps surprising that a country as far-flung as Australia has no central body like the US National Aeronautics and Space Administration (NASA) or the European Space Agency (ESA) to coordinate developments in communications technology. An early competence was built during the 1950s and 1960s in support of the joint United Kingdom/Australia testing programme at the Woomera rocket range and the NASA satellite-tracking network, but although Australia was one of the eleven founding members of Intelsat, during the twenty years of the consortium's operation, no Intelsat contracts have been placed with Australian companies for the supply of flight equipment. In fact, within the past year, the contract for a ground-control station was lost to Indonesia.

Although Australia will now supply the image-detection system for a new tripartite space telescope project with NASA and ESA, it had been previously thought that Australia's bids for international contracts would be spearheaded by participation in the now-defunct Starlab project, which faltered when Canada withdrew in March 1984. In the same month, CSIRO established a Space Science and Technology Study Group, which, in November, urged CSIRO to use its expertise to stimulate the industrial sector with contracts in such fields as ground sector space communications systems and remote sensing, and to collaborate in international projects such as the reusable US Spartan satellite and ESA's radar satellite ERS-1.

The local industry's share of the \$A330 million expenditure in the government's satellite-owning company Aussat amounts to about \$A63 million, with a possible extra \$A70 million through offsets. Aussat is due to have its first two Hughes domestic satellites launched from the space shuttle in July and October this year, with a third perhaps in mid-1986, to be launched by Arianespace. By the end of 1985, Australia will have spent about $\$$ A500 million on operational space systems such as Intelsat, Aussat and Inmarsat, but relatively little of the equipment will have been manufactured in Australia. More to the point, by 1995, the country's annual expenditure on spacerelated technology is estimated at between \$A370 and \$A500 million.

\section{Mongolia}

The directorship of COSSA will be filled by Dr Ken McCracken, at present chief of the CSIRO Division of Mineral Physics. Using Skylark rockets flown from Woomera, he was a pioneer of Australian $\mathrm{X}$-ray astronomy and introduced the use of Landsat satellite pictures into the management of Australian resources.

Introducing COSSA this week, Dr Paul
Wild, chairman of CSIRO, observed that if approved by cabinet for this year's budget, COSSA would spend \$A7 million in 198586 , rising to $\$ A 20$ million per annum at the end of the decade. In the international space market, a company could only get a contract to build part of a commercial satellite if it had done so before: no previous experience meant no contract. By letting out up to 70 per cent of the contracts for CSIRO's space experiments to Australian companies, he said, CSIRO will break this vicious circle. Jeffrey Sellar

\title{
Progress with problems
}

MongoliA's new Party leader, Dr Jambyn Batmonh, has sharply criticized the country's alleged progress in industrialization and the modernization of agriculture. Addressing the Central Committee of the Mongolian People's Revolutionary Party (MPRP) las month, he drew attention to the frequent waste of financial investment and human effort by the neglect of underlying scientific principle. His tone contrasted strongly with that of the official eulogies, only three weeks before, during the celebration of the diamond jubilee of the Mongolian People's Republic, which presented Mongolia as a shining example

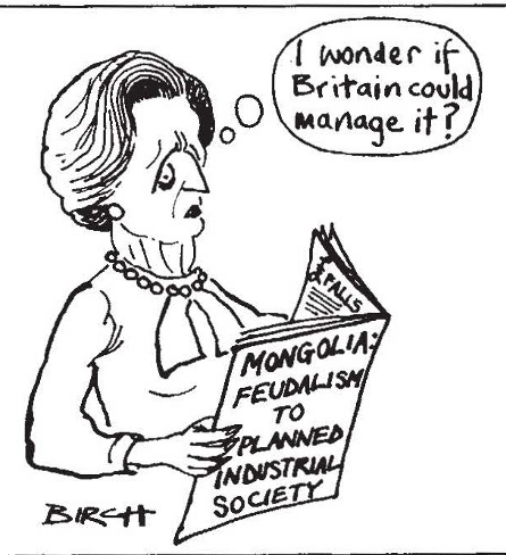

for Third World countries wishing to make the leap direct from feudalism to a centrally planned industrial society.

Mongolia's achievements, according to the jubilee data, are impressive. Since 1966, when the fifteenth congress of MPRP adopted a plan for "completing the building of socialism", major industrial centres have been established at Darkhan, Erdenet and Baganur, with industry now accounting for more than 30 per cent of the national income. Coal production has gone up sixfold, generation of electricity more than eightfold, mining for metal ores close to 40 -fold. More than 660,000 hectares of virgin land have been brought under cultivation and 20 "highly mechanized" state farms established.

Unfortunately, according to Dr Batmonh, investments have not always been properly planned to suit Mongolian conditions. Construction projects are not completed on schedule, and there is an increasing backlog of uncommissioned facilities, due to the inadequacy of the transport infrastructure. Insufficient allowance has been made by planners for the fact that, although construction materials are (theoretically) produced at a uniform rate throughout the year, most construction and installation work can be done only between late spring and early autumn and that, just when the building season starts, there are vast amounts of other heavy goods to be moved.

In agriculture, the establishment of modern farms has not been backed up by "good and stable crops"' for Mongolian conditions, nor the proper organization of pedigree stock-breeding on a "scientific basis" (a topic doubtless close to Dr Batmonh's heart, being himself the son of itinerant herdsmen). Water management is uncoordinated and, in some cases, neglect of the "features of soil fertility and the biology of plant cultivation and crop rotation" means that the construction of expensive irrigation systems has actually led to a falling-off of crop yields.

In the country's new industries, poor work at the design stage has led to high production costs, wastage of raw materials and insufficient use of equipment and machinery. Training of workers in modern techniques and production methods should be treated, Batmonh urged, as a matter of "very serious concern".

Mongolian specialists still, to a large extent, depend for advanced training on the Soviet Union (Mongolians hold first place there among foreign students), and the Soviet Union and the other Comecon countries have a number of technical cooperation projects with Mongolia, including a major geological survey of the country.

According to Batmonh, Party plans to make Mongolian industry and agriculture more productive include wider use of the "brigade organization"' of labour (payment on the basis of output of a team) and "socialist competition" between workers. These are, Batmonh explained, "tried methods" for involving workers in the implementation of large-scale plans.

Vera Rich 